\title{
Degradasi Mekanik Beton Mutu Tinggi Pasca Bakar
}

\author{
(Mechanical Degradation of Post Burn High Quality Concrete)
}

\author{
FAUZAN HAMDI, MUH. AMIR ZAINUDDIN, FARIDA GAFFAR
}

\begin{abstract}
Research on the effect of temperature on concrete is still a hot topic. The effect of temperature was measured on its mechanical properties and analyzed using descriptive statistical analysis. The desire of researchers to know accurately the shape, description, and influence of temperature on concrete is something that still needs further research. The researchers began to research by making concrete test objects which were then burned directly in the furnace. After that, testing is done on the test object in the form of compressive strength. The research that was carried out was the remains of a burning building. But so far the assessment research has not yet found a strong starting point. Broadly speaking, the problem examined in this study is that researchers want to know the magnitude of high quality concrete mechanical degradation after being burned at a certain temperature and compared with high quality concrete that is not burned. These results are expected to provide a basis for the repetition of buildings that use high quality concrete that has been burned. The results of the mechanical degradation test reviewed were the average compressive strength of high quality concrete at a normal temperature of $53.46 \mathrm{MPa}$, a temperature of $100^{\circ} \mathrm{C}$ of $34.93 \mathrm{MPa}$, a temperature of $300^{\circ} \mathrm{C}$ of $29.76 \mathrm{MPa}$, a temperature of $600^{\circ} \mathrm{C}$ of $25.57 \mathrm{MPa}$.
\end{abstract}

Keywords: High Quality Concrete, Post Burn, Mechanical

\section{PENDAHULUAN}

Salah satu tantangan yang dihadapi para ahli struktur (teknik sipil) adalah bagaimana menganalisis kekuatan struktur beton pada gedung akibat: (1) Temperatur tertinggi yang dialami elemen bangunan pada saat kebakaran, (2) Kekuatan sisa bangunan pasca kebakaran, (3)Teknik perkuatan bangunan sesuai keperluan sehingga fungsi bangunan dapat dikembalikan seperti sebelum terjadi kebakaran.

Untuk menjawab secara ilmiah tantangan tersebut sekaligus membantu masyarakat dalam menangani masalah ini secara tepat, telah dikembangkan berbagai metode penaksiran, baik secara non-destruktif maupun secara destruktif. Metode ini digunakan untuk dapat secara akurat temperature tertinggi yang pernah dialami bangunan, kekuatan sisa struktur bangunan pasca kebakaran, dan teknik perkuatan bangunannya. Berbagai masalah teknik yang menyangkut penaksiran kekuatan sisa dan teknik perkuatan elemen struktur tersebut hasilnya dimanfaatkan oleh pihak lain yang terkait, seperti bank, pemilik bangunan, kepolisian, pengacara hukum, dan perusahaan asuransi.

Sampai saat ini penelitian tentang pengaruh temperatur pada beton masih merupakan topik yang hangat diteliti. Pengaruh temperatur diukur sifat mekanik dan dianalisis dengan menggunakan analisis statistik deskriptif. Keinginan para peneliti untuk mengetahui secara akurat bentuk, gambaran, dan besar pengaruh temperatur terhadap beton merupakan hal yang masih perlu diteliti lebih lanjut. Para peneliti mulai meneliti dengan membuat benda uji beton yang kemudian dibakar langsung atau dibakar dalam oven atau tungku. Setelah itu, dilakukan pengujian pada benda uji berupa kuat tekan, kuat lentur, dan modulus elastisitas. Penelitian yang pernah dilakukan adalah sisa suatu bangunan yang telah terbakar. Namun sejauh ini penelitian penaksiran tersebut masih belum menemukan landasan awal yang kuat.

Secara garis besar masalah yang diteliti dalam penelitian ini adalah peneliti ingin mengetahui besar degradasi mekanik beton mutu tinggi 
setelah dibakar pada suhu tertentu dan dibandingkan dengan beton mutu tinggi yang tidak dibakar. Hasil ini diharapkan dapat memberikan dasar bagi penanggulangan bangunan yang telah terbakar yang menggunakan beton mutu tinggi.

Dengan memperhatikan berbagai permasalahan yang diakibatkan oleh struktur bangunan beton yang mengalami kebakaran baik secara sosial, material, finansial, dan berbagai masalah yang lainnya merupakan suatu hal yang perlu mendapatkan perhatian dan solusi dalam menyelesaikan permasalahan tersebut. Sehingga perlu menjadi perhatian khusus dalam penyelesaiannya. Salah satu cara mengatasi masalah tersebut, peneliti mengambil bagian yang bisa membatu dalam penyelesaian berupa mengetahui degradasi mekanik beton akibat pasca kebakaran. Tujuan dari penelitian ini adalah untuk mengetahui besar degradasi mekanik beton mutu tinggi akibat pasca bakar.

Mulyono (2006), mengungkapkan bahwa beton merupakan fungsi dari bahan penyusunnya yang terdiri dari bahan semen hidrolik, agregat kasar, agregat halus, air, dan bahan tambah.

Sagel dkk. (1994), menguraikan bahwa beton adalah suatu komposit dari bahan batuan yang direkatkan oleh bahan ikat.

Sirait (2009), menggunakan balok beton bertulang penampang empat persegi ukuran $15 \times 25 \times 320$, terletak pada tumpuan sederhana, bertulangan lemah. Waktu pembakaran mulai dari 30, 60, 90 dan 120 menit dengan balok yang berbeda pada suhu $500^{\circ} \mathrm{C}$ sejak awal hingga akhir pembakaran dan tanpa pembebanan. Pembebanan pada uji lentur menunjukkan penurunan daya pikul sebesar $26 \%$, demikian juga pada uji kuat tekan beton menunjukkan penurunan kuat tekan beton sebesar $65 \%$ dari kekuatan awal.

Ahmad dan Taufieq (2006), menyatakan bahwa terjadi penurunan kekuatan pada bangunan beton yang telah dioven. Pada penelitian ini didapatkan kuat tekan pada beton yang tidak dioven sebesar 240,0624 kg/cm2 . Kekuatan sisa beton yang dioven pada temperatur $200 \mathrm{oC}$ dan $400 \mathrm{oC}$ adalah $88,89 \%$ dan $70,15 \%$ dari kekuatan beton normal yang tidak dioven.

Menurut Zacoeb dan Anggraini (2005), perubahan temperatur yang cukup tinggi, seperti yang terjadi pada peristiwa kebakaran, akan membawa dampak pada struktur beton.
Karena pada proses tersebut akan terjadi suatu siklus pemanasan dan pendinginan yang bergantian, yang akan menyebabkan adanya perubahan fase fisis dan kimiawi secara kompleks. Hal ini akan mempengaruhi kualitas/kekuatan struktur beton tersebut. Pada beton normal mutu tinggi dengan suhu $1200 \mathrm{oC}$ terjadi penurunan kekuatan tekan sampai tinggal $40 \%$ dari kekuatan awal. Sedangkan pada beton mutu tinggi dengan Silikafume dan Superplasticizer akan mengalami perubahan yang cukup berarti pada suhu tinggi dimana kekuatannya tinggal $35 \%$.

Ahmad (2001), membahas kelayakan balok beton bertulang pascabakar secara analisis dan eksperimen. Penelitian dilakukan terhadap lima benda uji berbentuk balok beton bertulang. Empat balok dibakar di dalam tungku pada temperatur $200 \mathrm{oC}$ dan $400 \mathrm{oC}$ selama \pm 3 jam dan satu balok lain yang tidak dibakar sebagai pembanding. Hubungan tegangan-regangan memperlihatkan perubahan kemiringan kurva atau dengan kata lain terjadi penurunan kekakuan sejalan dengan kenaikan temperatur dan diikuti dengan penambahan regangan maksimum.

Sumardi (2000), kebakaran pada hakekatnya merupakan reaksi kimia dari combustible material dengan oksigen yang dikenal dengan reaksi pembakaran yang menghasilkan panas. Panas hasil pembakaran ini diteruskan ke massa beton/mortar dengan dua macam mekanisme yakni pertama secara radiasi yaitu pancaran panas diterima oleh permukaan beton sehingga permukaan beton menjadi panas. Pancaran panas akan sangat potensial, jika suhu sumber panas relatif tinggi. Kedua secara konveksi yaitu udara panas yang bertiup/bersinggungan dengan permukaan beton/mortar sehingga beton menjadi panas. Bila tiupan angin semakin kencang, maka panas yang dipindahkan dengan cara konveksi semakin banyak.

Tjokrodimuljo (2000), mengatakan bahwa beton pada dasarnya tidak diharapkan mampu menahan panas sampai diatas $250^{\circ} \mathrm{C}$. Akibat panas, beton akan mengalami retak, terkelupas (spalling), dan kehilangan kekuatan. Kehilangan kekuatan terjadi karena perubahan komposisi kimia secara bertahap pada pasta semennya. Selain hal tersebut di atas, panas juga menyebabkan beton berubah warna. Bila beton dipanasi sampai suhu sedikit di atas $300^{\circ} \mathrm{C}$, beton akan berubah warna menjadi merah muda. Jika di atas $600^{\circ} \mathrm{C}$, akan menjadi abu-abu agak hijau. Dengan demikian, secara 
kasar dapat diperkirakan berapa suhu tertinggi selama kebakaran berlangsung berdasarkan warna permukaan beton pada pemeriksaan pertama.

Rahmah (2000), menggunakan silinder hasil core case berdiameter $5 \mathrm{~cm}$ dari suatu model balok beton bertulang yang dibakar pada temperatur $200^{\circ} \mathrm{C}, 400^{\circ} \mathrm{C}, 600^{\circ} \mathrm{C}$, dan $800^{\circ} \mathrm{C}$. Hasil dari penelitian ini adalah terjadi perubahan kuat tekan tiap sentimeter kedalaman core case beton sebesar $0,4 \%$; sedangkan perubahan modulus elastisitas tiap sentimeternya berkisar $1,2 \%-2,2 \%$.

Mulyono (2006), mengemukakan bahwa kuat tekan beton mengidentifikasikan mutu sebuah struktur di mana semakintinggi tingkat kekuatan struktur yang dikehendaki, maka semakin tinggi pula mutu beton yang dihasilkan. Kuat tekan karakteristik $\sigma^{\prime} \mathrm{bk}$ dihitung menggunakan rumus:

$$
\sigma^{\prime} \mathrm{bk}=\sigma^{\prime} \mathrm{bm}-1,64
$$

dengan taraf signifikan 5\%. Adapun faktor lain yang dapat mempengaruhi mutu kekuatan beton seperti yang dikemukakan oleh Mulyono (2006), yaitu: (1) Proporsi bahan penyusun, (2) Metode pencampuran, (3) Perawatan (4) Keadaan pada saat pengecoran.

\section{METODE PENELITIAN}

\section{Waktu dan Tempat Penelitian}

Penelitian ini dilaksanakan selama \pm 4 bulan yang berlangsung dari bulan Mei 2018 September 2017. Tempat penelitian ini dilaksanakan di Laboratorium Fakultas Teknik Universitas Muhammadiyah Makassar dan tungku pembakaran batubata di Kecamatan Bontonompo, Kabupaten Gowa, Provinsi Sulawesi Selatan.

\section{Bahan dan Alat}

Bahan yang digunakan dalam penelitian ini terdiri dari semen Portland Composit, agregat halus Sungai Je'ne'berang Gowa, agregat kasar yang berasal dari batu pecah Bili-Bili dan air
PDAM. Adapun alat yang digunakan adalah alat-alat laboratorium untuk uji karakteristik material, mould untuk mal pembuatan benda uji, mixer concrete untuk mencampur adukan beton, slump test digunakan untuk mengukur kelecakan beton segar, tungku pembakaran sampel, alat pengukur suhu digital infrared thermometer $-50^{\circ} \mathrm{C} \sim 900^{\circ} \mathrm{C}$ dan mesin uji tekan beton.

Bahan yang digunakan untuk penelitian harus disiapkan terlebih dahulu, ditentukan kualitas masing-masing bahan susunnya, serta dibuatkan cetakan untuk tempat benda uji yang telah direncanakan. Alat yang digunakan pada penelitian ini sebelumnya telah diperiksa kondisi dan kemampuannya serta telah dikalibrasi terlebih dahulu. Benda uji silinder dibuat dengan cara memasukkan beton segar dari molen ke dalam cetakan silinder ukuran 15 $\mathrm{cm}$ x $30 \mathrm{~cm}$ yang telah diolesi minyak pelumas. Pengisian ini dilakukan secara bertahap, yaitu tiap sepertiga bagian dilakukan penumbukan dengan tongkat baja sebanyak \pm 25 kali. Setelah 24 jam, cetakan dibuka kemudian dilakukan perawatan dengan direndam di dalam bak air selama 28 hari. Selanjutnya benda uji kemudian dibakar selama tiga jam pada temperatur $100^{\circ} \mathrm{C}, \quad 300^{\circ} \mathrm{C}$ dan $600^{\circ} \mathrm{C}$, masing-masing sebanyak 4 buah dan 4 buah tidak dibakar digunakakan sebagai benda uji pengontrol. Data diperoleh melalui pengujian tekan di laboratorium dengan menggunakan mesin uji kuat tekan untuk semua benda uji. Hasil uji tekan beton berupa gaya $(\mathrm{P})$ yang terjadi pada saat benda uji hancur. Berdasarkan data gaya tekan dan luas penampang silinder, maka kuat tekan beton dapat dihitung dengan menggunakan rumus:

$$
f=\mathrm{P} / \mathrm{A}
$$

dimana $: f=$ Kuat tekan $\left(\mathrm{kg} / \mathrm{cm}^{2}\right)$

$\mathrm{P}=$ Gaya tekan $(\mathrm{kg})$

$\mathrm{A}=$ Luas penampang kubus $\left(\mathrm{cm}^{2}\right)$

Analisis data yang dilakukan adalah analisis statistik, digunakan untuk mengetahui rata-rata kuat tekan beton dan rata-rata berat isi beton yang belum dan telah dibakar. 


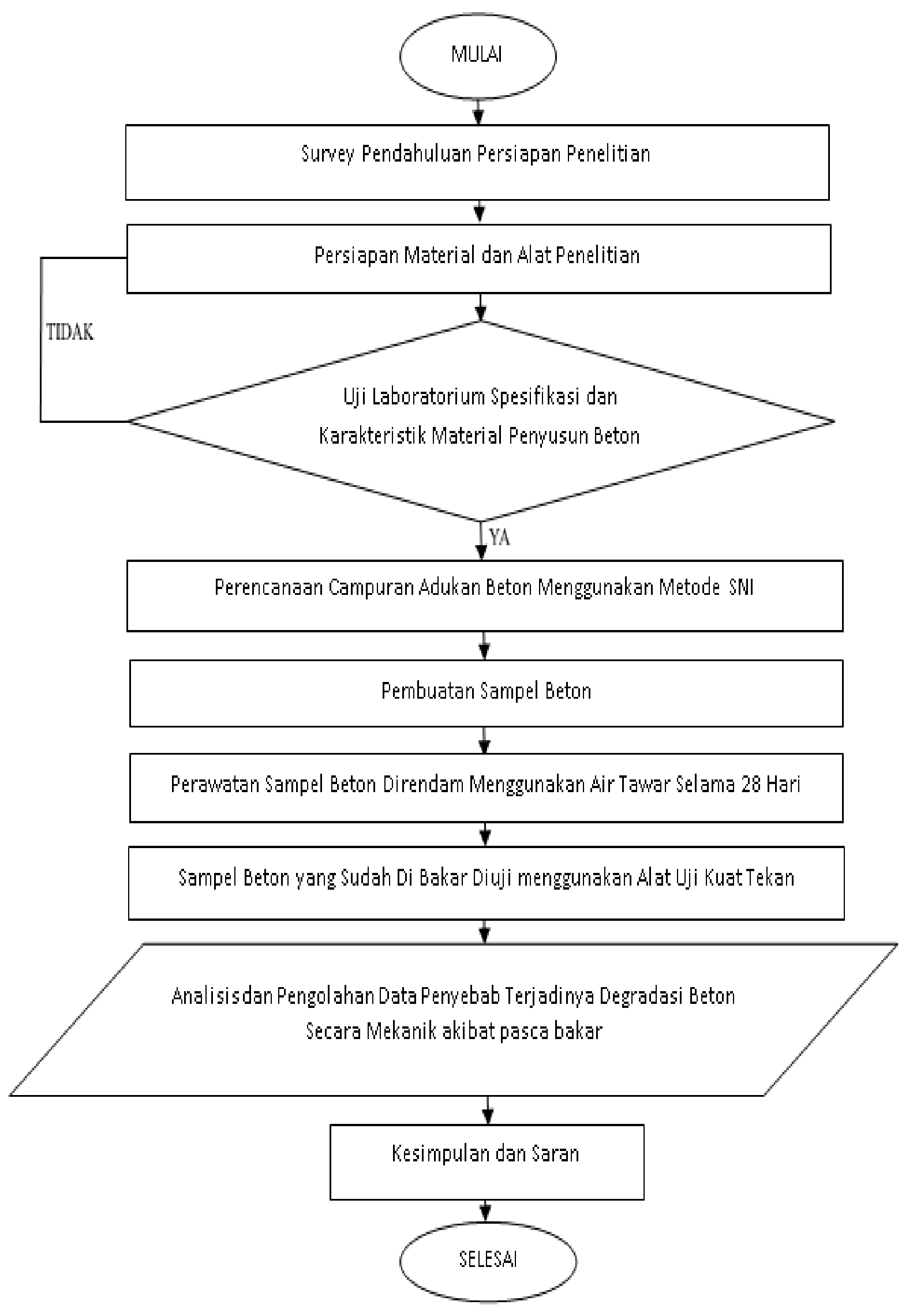

Gambar 1. Bagan Alir Penelitian 


\section{HASIL DAN PEMBAHASAN}

\section{Karakteristik Material Penyusun Beton}

Semen penyusun beton menggunakan Portland Cement Composite (PCC) yang diperoleh dari pasar lokal di Makassar, Sulawesi Selatan.

Agregat penyusun beton terdiri dari agregat halus yang diperoleh dari Sungai Je'neberang, Kabupaten Gowa, Provinsi Sulawesi Selatan dan agregat kasar yang diperoleh dari Sungai Bili-Bili yang berbentuk batu pecah hasil pabrik "stone cruser" Kabupaten Gowa, Sulawesi Selatan.
Hasil pemeriksaan karakteristik agregat halus (pasir) menunjukkan bahwa memenuhi syarat spesifikasi SNI sehingga agregat halus dapat digunakan sebagai campuran beton. Hasil pemeriksaan tersebut dapat dilihat pada tabel 1 berikut.

Hasil pemeriksaan uji karakteristik agregat kasar (batu pecah) menunjukkan bahwa memenuhi syarat spesifikasi SNI sehingga agregat kasar dapat digunakan sebagai campuran beton. Hasil pemeriksaan tersebut dapat dilihat pada tabel 2.

Komposisi bahan campuran beton mutu tinggi $\mathrm{f}^{\prime} \mathrm{c}=50 \mathrm{MPa}$ menggunakan faktor air semen (FAS) 0.3 dapat dilihat pada tabel 3 .

TABEL 1. Hasil pemeriksaan karakteristik agregat halus (pasir)

\begin{tabular}{llcccc}
\hline \multirow{2}{*}{ NO } & \multirow{2}{*}{ KARAKTERISTIK AGREGAT } & Spesifikasi SNI & INTERVAL & $\begin{array}{c}\text { HASIL } \\
\text { PEMERIKSAAN }\end{array}$ & KETERANGAN \\
\hline 1 & Kadar lumpur & SNI 03-4141-1996 & Maks 5\% & $0,00 \%$ & Memenuhi \\
\hline 2 & Kadar organik & SNI 03-2816-1992 & $<$ NO. 3 & No. 1 & Memenuhi \\
\hline 3 & Kadar air (Wp) & SNI 03-1971-1990 & $0,5 \%-5 \%$ & $0,00 \%$ & Memenuhi \\
\hline 4 & Berat volume & SNI 03-4804-1998 & & & \\
\hline & a. Kondisi lepas & $1,4-1,9 \mathrm{~kg} /$ liter & 0,00 & Memenuhi \\
\hline & b. Kondisi padat & $1,4-1,9 \mathrm{~kg} /$ liter & 0,00 & Memenuhi \\
\hline 5 & Penyerapan (Rp) & SNI 03-1970-1990 & $0,2 \%-2 \%$ & $0,00 \%$ & Memenuhi \\
\hline 6 & Berat jenis spesifik kering permukaan & SNI 03-1970-1990 & $1,6-3,3$ & $0,00 \%$ & Memenuhi \\
\hline 7 & Modulus kehalusan & SNI 03-1968-1990 & $1,50-3,80$ & Lolos (\%) & Memenuhi \\
\hline
\end{tabular}

TABEL 2. Hasil pemeriksaan karakteristik agregat kasar (batu pecah

\begin{tabular}{llcccc}
\hline \multirow{2}{*}{ NO } & \multirow{2}{*}{ KARAKTERISTIK AGREGAT } & Spesifikasi SNI & INTERVAL & \multicolumn{2}{c}{ HASIL } \\
PEMERIKSAAN & KETERANGAN \\
\hline 1 & Kadar lumpur & SNI 03-4141-1996 & Maks 5\% & $0,00 \%$ & Memenuhi \\
\hline 2 & Kadar organik & SNI 03-2816-1992 & $<$ NO. 3 & No. 1 & Memenuhi \\
\hline 3 & Kadar air (Wp) & SNI 03-1971-1990 & $0,5 \%-5 \%$ & $0,00 \%$ & Memenuhi \\
\hline 4 & Berat volume & SNI 03-4804-1998 & & & \\
\hline & a. Kondisi lepas & $1,4-1,9 \mathrm{~kg} /$ liter & 0,00 & Memenuhi \\
\hline & b. Kondisi padat & $1,4-1,9 \mathrm{~kg} /$ liter & 0,00 & Memenuhi \\
\hline 5 & Penyerapan (Rp) & SNI 03-1970-1990 & $0,2 \%-2 \%$ & $0,00 \%$ & Memenuhi \\
\hline 6 & Berat jenis spesifik kering permukaan & SNI 03-1970-1990 & $1,6-3,3$ & $0,00 \%$ & Memenuhi \\
\hline 7 & Modulus kehalusan & SNI 03-1968-1990 & $1,50-3,80$ & Lolos $(\%)$ & Memenuhi \\
\hline
\end{tabular}

TABEL 3. Komposisi bahan campuran beton mutu tinggi

\begin{tabular}{clrc}
\hline NO & $\begin{array}{c}\text { BAHAN } \\
\text { BETON }\end{array}$ & $\begin{array}{c}\text { BERAT BETON } \\
(\mathbf{K g} / \mathbf{m 3})\end{array}$ & $\begin{array}{c}\text { PERBANDINGAN } \\
\text { KOMPOSISI BAHAN }\end{array}$ \\
\hline 1 & Air Tawar & 202 & 0,32 \\
\hline 2 & Semen & 639 & 1 \\
\hline 3 & Pasir & 581 & 0,91 \\
\hline 4 & Batu Pecah & 858 & 1,34 \\
\hline
\end{tabular}




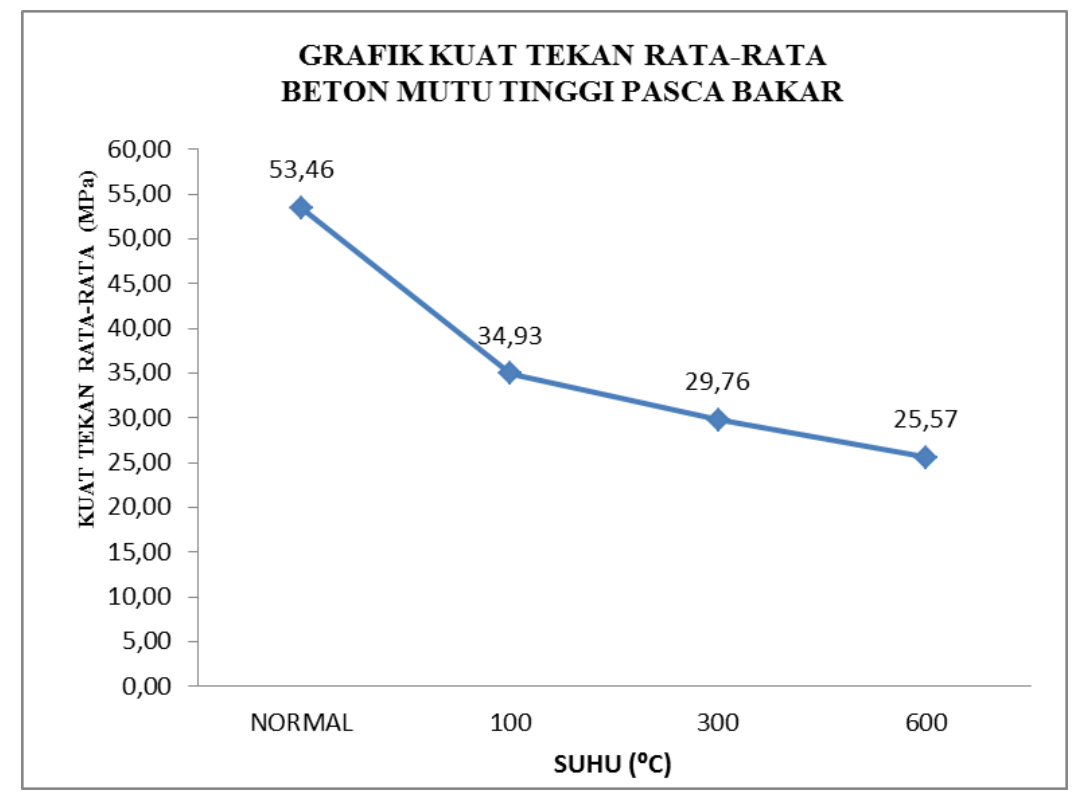

GAMBAR 2. Grafik hasil kuat tekan rata-rata beton pasca bakar

\section{Hasil Uji Degradasi Mekanik Beton Mutu Tinggi Pasca Bakar}

Hasil pengujian degradasi mekanik beton mutu tinggi dilakukan dengan cara uji kuat tekan beton yaitu didapat kuat tekan rata-rata beton mutu tinggi pada suhu normal sebesar 53,46 $\mathrm{MPa}$, suhu $100^{\circ} \mathrm{C}$ sebesar $34,93 \mathrm{MPa}$, suhu $300^{\circ} \mathrm{C}$ sebesar $29,76 \mathrm{MPa}$, suhu $600^{\circ} \mathrm{C}$ sebesar 25,57 MPa. Hasil kuat tekan beton mutu tinggi dapat dilihat pada gambar 2 .

\section{KESIMPULAN}

Berdasarkan hasil dan pembahasan penelitian eksperimental laboratorium ini, diperoleh kesimpulan yaitu terjadi degradasi mekanik beton mutu tinggi akibat pasca bakar. Berikut hasil uji kuat tekan rata-rata beton mutu tinggi pada suhu normal sebesar 53,46 $\mathrm{MPa}$, suhu $100^{\circ} \mathrm{C}$ sebesar $34,93 \mathrm{MPa}$, suhu $300^{\circ} \mathrm{C}$ sebesar 29,76 MPa, suhu $600^{\circ} \mathrm{C}$ sebesar 25,57 Mpa.

\section{UCAPAN TERIMA KASIH}

Syukur Alhamdulillah kami panjatkan kehadirat Allah SWT atas terlaksananya penelitian dan hasil yang dicapai dalam penelitian ini.

Tdk lupa kimi ucapkan terimakasih kepada:
1. Rektor
Universitas
Muhammadiyah

2. Dekan Fakultas Teknik Universitas Muhammadiyah Makassar

3. Ketua Jurusan Teknik Sipil Fakultas Teknik Universitas Muhammadiyah Makassar

4. Kepala Laboratorium Teknik Universita Muhammadiyah Makassar beserta jajarannya.

5. LP3M Universitas Muhammadiyah Makassar

6. Kemen Ristek Dikti

7. Dan semua pihak yang terlibat dalam pelaksanaan kigiatan penelitian ini.

\section{DAFTAR PUSTAKA}

Ahmad, I.A., 2001, Tinjauan Kelayakan Balok Beton Bertulang Pascabakar Secara Analisis dan Eksperimen, Yogyakarta: Tesis, Program Pasca Sarjana Universitas Gadjah Mada.

Ahmad, I.A. dan Taufieq, N.A.S., 2006, Tinjauan Kelayakan Forensic

Engineering Dalam Menganalisis Kekuatan Sisa Bangunan Pasca Kebakaran, Makassar: Laporan Penelitian Dosen Muda. Jurusan Sipil dan Perencanaan Fakultas Teknik Universitas Negeri Makassar,.

Mulyono, T., 2006, Teknologi Beton, Yogyakarta: Penerbit Andi. 
PBI, 1971, Peraturan Beton Bertulang Indonesia 1971 N.I.-2, Cetakan ke-7, Bandung: Departemen Pekerjaan Umum dan Tenaga Listrik Direktorat Jenderal Ciptakarya Direktorat Penyelidikan Masalah Bangunan.

Rahmah, S.N., 2000, Analisis Material Beton Pasca Bakar (Tinjauan Sifat Mekanik dan Kimiawi), Yogyakarta: Tesis, Program Pasca Sarjana Universitas Gadjah Mada.

Sagel, R., Kole, P. dan Kusuma. G., 1994, Pedoman Pengerjaan Beton Berdasarkan SKSNI T-15- 1991-03, Jakarta: Cetakan Keempat, Erlangga.

Sirait, 2009, Kajian Perilaku Beton Bertulang Pasca Bakar, Studi Penelitian, diakses Pada 25 juli 2009, http://bppft. brawijaya.ac.id/?hlm=bp enelitian \&view $=$ full \& thnid $=2005 \&$ pid $=1$ 153962006

Sumardi, P.C., 2000, Aspek Kimia Beton Pasca Bakar, Yogyakarta: Kursus Singkat Evaluasi dan Penanganan Struktur Beton yang Rusak Akibat Kebakaran dan Gempa, 24-25 Maret.

Tjokrodimulyo, K., 2000, Pengujian Mekanik Laboratorium Beton Pasca Bakar, Yogyakarta: Nafri.
Zacoeb, A. dan Anggraini, R., 2005, Kuat Tekan Beton Pasca Bakar, diakses pada 31 juli 2009, http://bppft . b r a w i j a y a a c. i d / ? $\mathrm{hlm}=$ bpenelitian $\&$ view $=$ full $\&$ thnid $=2005$ \&pid=1153962006.

PenUlis:

Fauzan Hamdi

Prodi Teknik Sipil, fakultas teknik, Universitas Muhammadiyah Makassar, Jalan Sultan Alauddin no.259, makasar

Email: fauzanhamdiunismuh@gmail.com

Muh. Amir Zainuddin

Prodi Teknik Sipil, fakultas teknik, Universitas Muhammadiyah Makassar, Jalan Sultan Alauddin no.259, makasar

Email: amirzainuddin20@yahoo.co.id

Farida Gaffar

Prodi Teknik Sipil, fakultas teknik, Universitas Muhammadiyah Makassar, Jalan Sultan Alauddin no.259, makasar

Email: gaffarfarida970@yahoo.com 